\title{
Modeling Dynamic System for Prediction of Dengue Hemorrhagic Fever in Maros District
}

\author{
Ilham Salam ${ }^{1,2}$, A. Arsunan Arsin ${ }^{3 *}$, Atjo Wahyu ${ }^{4}$, Agus Bintara Birawida ${ }^{5}$, Aminuddin Syam ${ }^{6}$, Anwar Mallongi $^{5}$, Sukri Palutturi ${ }^{7}$, \\ Farid Agushybana ${ }^{8}$, Aisyah Aisyah $^{9}$, Ahmad Yani $^{10}$, Muhammad Akbar Nurdin $^{11}$, Rezki Elisafitri ${ }^{3}$ \\ ${ }^{1}$ Public Health Study Program, Faculty of Sports Science, Manado State University, Manado, Indonesia; ${ }^{2}$ Doctoral Study \\ Program, Faculty of Public Health, Hasanuddin University, Makassar, Indonesia; ${ }^{3}$ Department of Epidemiology, Faculty of \\ Public Health, Hasanuddin University, Makassar, Indonesia; ${ }^{4}$ Department of Occupational Safety and Health, Faculty of \\ Public Health, Hasanuddin University, Makassar, Indonesia; ${ }^{5}$ Department of Environmental Health, Faculty of Public Health, \\ Hasanuddin University, Makassar, Indonesia; ${ }^{6}$ Nutrition Study Program, Faculty of Public Health, Hasanuddin University, \\ Makassar, Indonesia; ${ }^{7}$ Department of Health Policy Administration, Faculty of Public Health, Hasanuddin University, Makassar, \\ Indonesia; ${ }^{8}$ Public Health Study Program, Faculty of Public Health, Diponegoro University, Semarang, Indonesia; ${ }^{9}$ Department \\ of Agribusiness, Pangkajene Islands State Agricultural Polytechnic, Pangkep, Indonesia; ${ }^{10}$ Department of Health Promotion \\ and Behavioral Sciences, Faculty of Public Health, University of Muhammadiyah Palu, Palu, Indonesia; ${ }^{11}$ Public Health Study \\ Program, Faculty of Public Health, Cenderawasih University, Jayapura, Indonesia
}

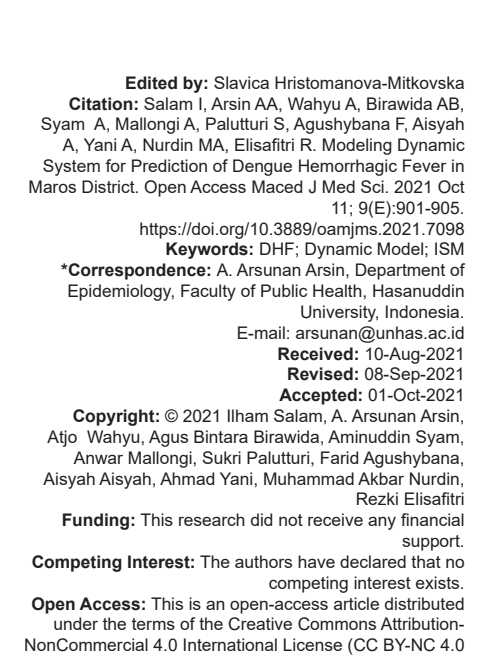

\section{Abstract}

BACKGROUND: Efforts to control the incidence of dengue hemorrhagic fever (DHF) have been carried out intensively, however, there is no significant reduction in the number of DHF sufferers. Meanwhile, the predictive model is expected to be an early warning to anticipate the incidence of DHF.

AIM: Therefore, this study aims to determine the dynamic model for predicting dengue fever incidence in Maros Regency from 2020 to 2040.

METHODS: This study used the research and development ( $R$ and $D)$ method with a dynamic systems approach. The study was conducted in Maros Regency and the data on dengue cases in Maros Regency from 2014 to 2018 were used as samples. Meanwhile, interpretive structural modeling (ISM) was used to determine policy scenarios in reducing dengue cases while the analysis of the dynamic model of dengue fever was conducted using the Powersim program.

RESULTS: The critical elements of DHF prevention in the Maros Regency include the Jumantik program, 3M Plus early warning systems, and outreach. Furthermore, the prediction of the average incidence of dengue fever from 2020 to 2040 has decreased based on dynamic model simulations by applying the Jumantik scenario (46.8\%), 3M Plus $(61.17 \%)$, early warning systems $(74.4 \%)$, counseling $(52.12 \%)$, and the combined scenario $(97.87 \%)$.

CONCLUSIONS: The incidence of dengue fever in the Maros Regency is prevented and controlled by the combination of the Jumantik program, 3M Plus, early warning systems, and counseling.

\section{Introduction}

Tropical diseases such as dengue hemorrhagic fever (DHF), malaria, and tuberculosis remain global health problems [1], [2], [3]. Meanwhile, several efforts that have been carried out to control these diseases have not significantly reduced the number of sufferers, especially DHF. An estimation has shown that 390 million dengue infections occur each year and 96 million manifests clinically [4]. Out of the population at risk of this disease, 1.3 billion live in 10 countries of the WHO regional area in Southeast Asia, which are dengue-endemic areas [5].

DHF is caused by the dengue virus and transmitted through mosquito bites from the genus
Aedes [6]. Moreover, behavioral factors, population mobility, and climaticfactors such as rainfall, temperature, and humidity affect dengue incidence [7] [8], [9] Meanwhile, people's behavior is changed through a positive deviance approach that focuses on the local community behavior and through outreach to increase community knowledge and attitudes [10], [11]. Strengthening of the institutional system also plays a role in preventing and controlling dengue cases [12]. In addition, the detection and mapping of dengue virus serotypes is essential to monitor transmission [13].

Maros Regency is among the areas in South Sulawesi Province that are prone to dengue fever. This is due to the high incidence of dengue fever and its varying tendency. In 2013, the number of DHF sufferers in Maros Regency was 245 cases with an incidence 
rate (IR) of 73.84 per 100,000 population and three deaths with a case fatality rate (CFR) of 1.22 . The IR DHF in Maros Regency in 2014 increased to 133.79 per 100,000 population in 2014 and decreased to 117.01 in 2014, while in 2016, it increased to 183.15 . Meanwhile, the high rate of DHF morbidity in this regency is due to poor environmental conditions and the inadequate activity of Mosquito Nest Eradication (PSN) in the community [14].

Due to the high incidence of DHF in the Maros Regency, studies are conducted on the development of the incidence through dynamic modeling of dengue fever prediction from 2020 to 2040 . This dynamic model approach describes the increased incidence as a part of a complex system in the real world into a simple model. Furthermore, the dynamic system modeling is expected to predict future dengue events and serve as an early warning in anticipating the incidence.

\section{Methods}

\section{Research location and design}

The study was conducted in Maros Regency, South Sulawesi Province, because the regency is a dengue-endemic area. This study design is a research and development ( $R$ and $D$ ) method through a dynamic systems approach.

\section{Population and sample research}

DHF incidence data recorded in the Health Office of Maros Regency from 2014 to 2018 are used samples in this study.

\section{Data collection}

The secondary data used in this study were from the Maros District Health Office in the form of morbidity, mortality, and healing dengue disease. Furthermore, the climatological data were from the Maros Regency Meteorology, Climatology, and Geophysics Agency.

\section{Data analysis}

Dynamic modeling of dengue event prediction begins with making a flowchart prediction model for the fever. Interpretive structural modeling (ISM) was used to determine the right policy scenario in reducing cases. In implementing the ISM model, interviews were conducted with stakeholders from academia, practitioners, and the government to obtain ideas for controlling the incidence of DHF in the regency. Furthermore, the analysis was carried out using ISM through the Powersim program based on the interview data.

\section{Research Results}

\section{Key elements in the prevention of DHF}

The analysis of DHF prevention 14 sub-elements in Maros Regency based on interviews with stakeholders showed that the sub-elements with a considerable driving power in the prevention program are Jumantik, 3M Plus, early warning systems, and extension programs (Figure 1).

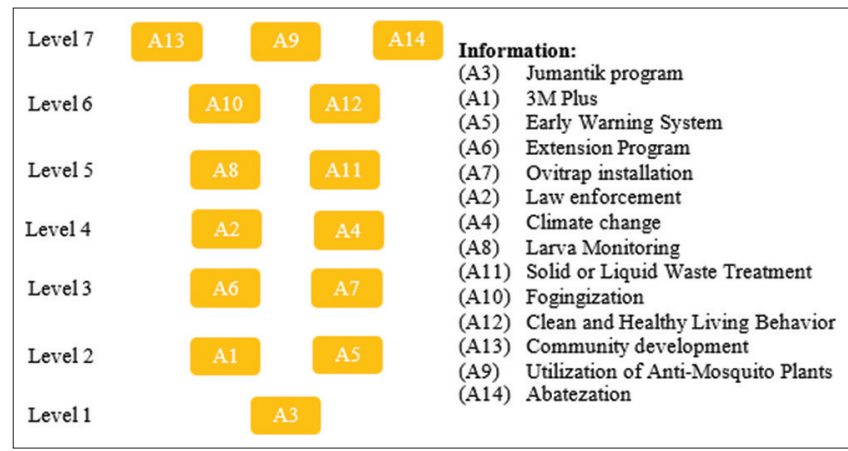

Figure 1: Hierarchy diagram of sub-element of DHF disease prevention in Maros Regency

\section{Do nothing scenarios}

Estimation of DHF average incidence based on model simulation results for 20 years (2020-2040) in Maros Regency in the do-nothing scenario, showed a decrease in DHF cases. The number of DHF cases in 2020 was 188 cases, while in 2040, it decreased to 184 with a percentage of $2.1 \%$ (Figure 2).

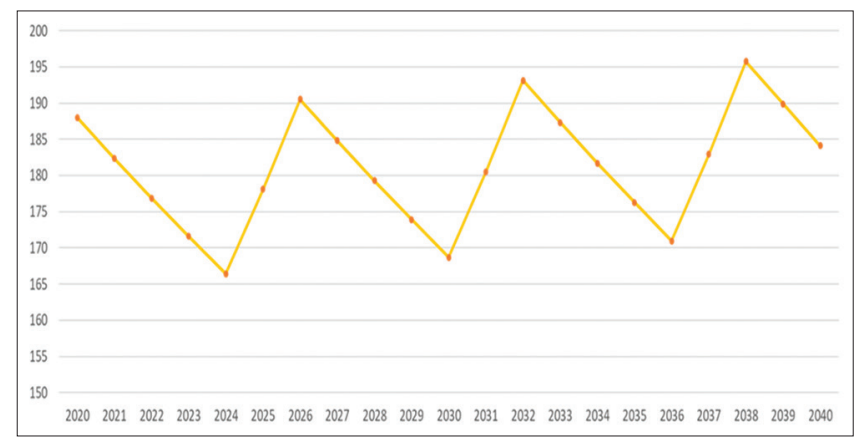

Figure 2: Prediction model of DHF in Maros Regency 2020-2040 with the do-nothing scenario

\section{Jumantik scenario}

Estimating the average incidence of DHF based on dynamic model simulation results with the Jumantik scenario for 20 years (2020 to 2040) showed a decrease in cases with $46.8 \%$. The number of DHF cases in 2020 was 188 cases while it decreased to 100 in 2040 (Figure 3).

\section{$3 M$ plus scenario}

The estimated average incidence of dengue fever in Maros Regency based on the results of the 


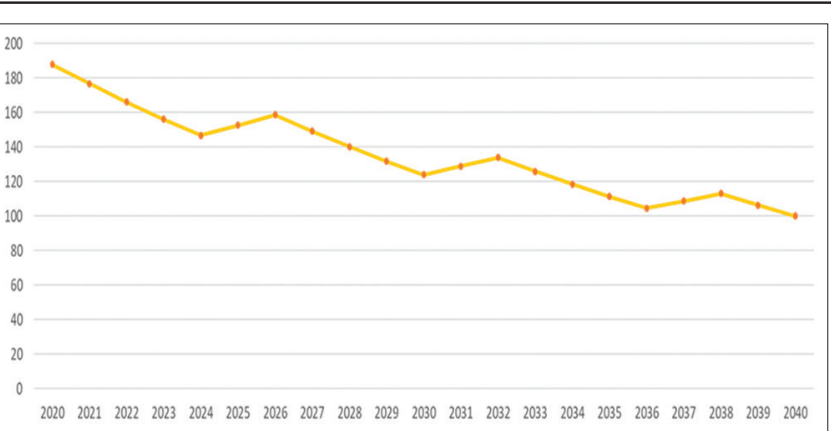

Figure 3: Prediction model of DHF in Maros Regency 2020-2040 with the Jumantik scenario

dynamic model simulation using the $3 \mathrm{M}$ Plus scenario for 20 years (2020-2040) has decreased. Meanwhile, the number of dengue cases in 2020 was 188 cases, while in 2040 , it was 73 , with a decrease of $61.17 \%$ (Figure 4).

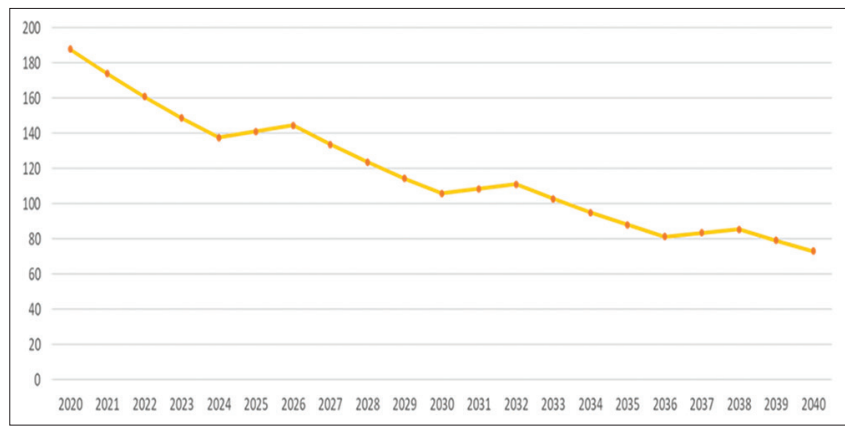

Figure 4: Prediction model of DHF in Maros Regency 2020-2040 with the $3 \mathrm{M}$ Plus scenario

\section{Early warning system scenarios}

The estimated average incidence of DHF based on dynamic model simulation results using an early warning system scenario for 20 years (20202040 ) in the Maros Regency showed a decrease of $74.4 \%$. The number of dengue cases in 2020 was 188 and decreased to 48 in 2040 (Figure 5).

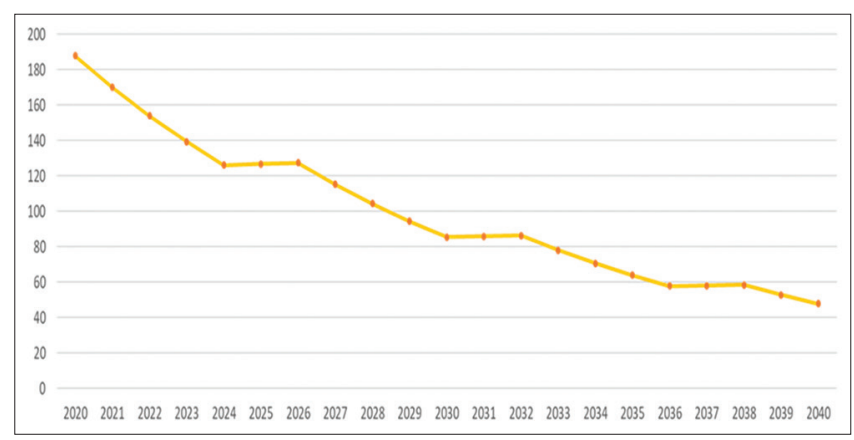

Figure 5: Prediction model of DHF in Maros Regency 2020-2040 with early warning system scenarios

\section{Extension scenarios}

Figure 6 shows the estimated average incidence of DHF based on a dynamic model simulation with a scenario for 20 years (2020-2040) that had a

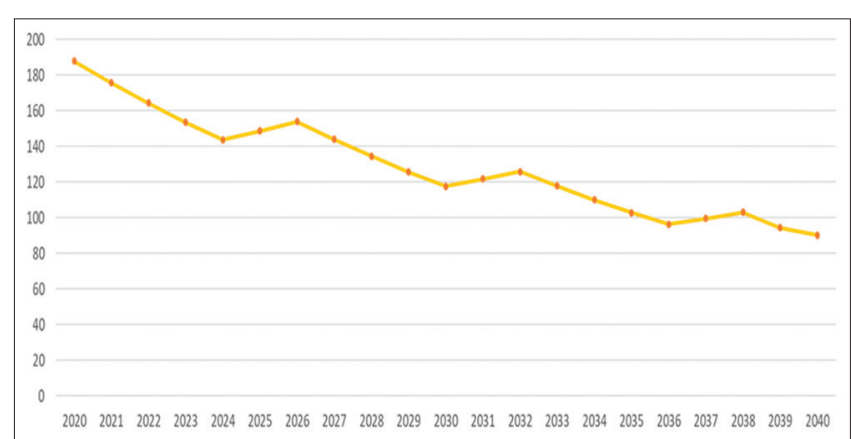

Figure 6: Prediction model of DHF in Maros Regency 2020-2040 with extension scenarios

decrease in cases. The number of dengue cases in 2020 was 188 , while in 2040 , it was 90 , with a decline of $52.12 \%$.

\section{Combined scenarios}

Estimating the average incidence of DHF based on dynamic model simulation results using a combined scenario (Jumantik, 3M Plus, early warning system, and counseling) for 20 years (2020-2040) has decreased. The number of dengue cases in 2020 was 188 , while in 2040 , it was 4 , with a decrease of $97.87 \%$ (Figure 7)

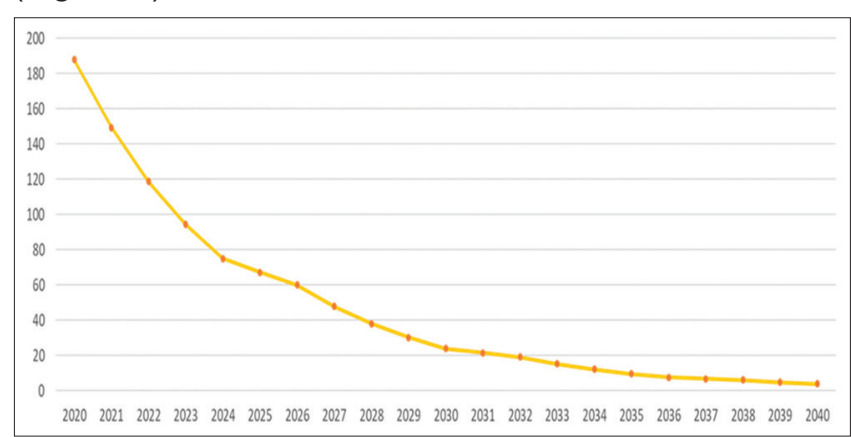

Figure 7: Prediction model of DHF in Maros Regency 2020-2040 with combined scenarios

\section{Discussion}

The sub-elements that have a considerable driving power in the DHF prevention program in Maros Regency are the Jumantik program, 3M Plus, early warning systems, and counseling. Meanwhile, dengue hemorrhagic fever (DHF) is a common disease in tropical regions that usually cause extraordinary events (KLB). Community participation is required to control mosquito larvae that cause DHF through continuous larva checks. To increase community participation, it is necessary to have a Jumantik cadre (Juru Pemantau Jentik) [15]. Supriayana's study showed that controlling dengue incidence through the "One Jumantik One House" program increased community-based family 
participation and empowerment for prevention [16]. Meanwhile, government attention to the Jumantik cadres requires improvement by providing facilities and tools to support the cadres in carrying out delegated duties.

The 3M Plus action is carried out to eradicate and destroy the dengue mosquito vector chain. A previous study by Moreira showed that 3M Plus activities such as draining and covering water reservoirs, as well as using mosquito repellent insecticides were related to the dengue incidence [17] This has a significant impact in controlling breeding places for mosquito nests and eradicating larvae before growing into adult mosquitoes. Moreover, prevention and control of dengue are carried out earlier [18].

The dengue fever early warning system is an effort to prevent and overcome dengue cases. This system is designed to predict outbreaks and avoid dengue cases by assisting in timely decision-making [19]. Furthermore, the system provides accurate and up-todate data to prevent dengue. Moreover, climatic and non-climatic information is used as an epidemiological tool for a dengue outbreak early warning system that enables prevention, vector control, identification of highrisk populations, and increases the preparedness of health-care facilities and workers as well as the public. This minimizes potential harm to society by prioritizing health services and limited resources and implementing vector control activities before an epidemic occurs [20].

Outreach activities and interpersonal communication regarding dengue are essential to improve good dengue prevention behavior in the community [21]. A previous study by Hasanah showed that health education on dengue significantly affected family behavior in preventing the disease [22]. Similarly, Baequni in Jakarta showed that the provision of health education in posters and flipcharts to elementary school students effectively triggered dengue eradication and prevention behavior [23]. Therefore, health workers need to conduct education on DHF and its prevention regularly to reduce the incidence of DHF.

The most effective scenario to reduce dengue cases in Maros Regency in the next 20 years is the combination of all methods, namely, the Jumantik program, 3M Plus, early warning systems, and counseling. This is in contrast with Rasmanto's study, which showed that the most useful scenarios to control dengue fever were the abatezation and fogging scenarios [24]. The difference in the results of this study could be caused by several factors such as sociocultural, community behavior, and environmental factors in the research location.

\section{Conclusions}

Based on the results, the most adequate model for predicting dengue incidence in Maros Regency from 2020 to 2040 is the combination of the Jumantik program scenario, $3 \mathrm{M}$ Plus, early warning systems, and counseling. Therefore, the combined method is used as a prevention and control strategy to reduce the rate of increase in DHF in Maros Regency and be considered to find the best way of increasing the effectiveness of the DHF disease prevention program.

\section{References}

1. Salam I, Arsin AA, Wahyu A, Syam A, Birawida AB, Mallongi A, et al. Eco-epidemiological analysis of dengue hemorrhagic fever (DHF) in Makassar city. Indian J Public Health Res Dev. 2019;10(12):1246-50. https://doi.org/10.37506/v10/i12/2019/ ijphrd/192217

2. Noor N, Arsunan A, Marleni N, Mallongi A. Algorithm malaria diagnosis as a result of the comparison between clinical symptoms and microscopy test in the population central Sulawesi Province. Asian J Epidemiol. 2017;10(1):32-6. https:// doi.org/10.3923/aje.2017.32.36

3. Amelia AR, Amiruddin R, Arsunan AA, Bahar B, Hasnik S, Rahardjo SP. Environmental analysis related to pulmonary TB incidence in work area of puskesmas kaluku bodoa Makassar city. Indian J Public Health Res Dev. 2018;9(8):1512-7. https:// doi.org/10.5958/0976-5506.2018.00947.6

4. Bhatt S, Gething PW, Brady OJ, Messina JP, Farlow AW, Moyes $\mathrm{CL}$, et al. The global distribution and burden of dengue. Nature. 2013;496(7446):504-7. https://doi.org/10.1038/ nature 12060

PMid:23563266

5. World Health Organization. Dengue and Severe Dengue. Geneva: World Health Organization; 2021c. Available from: https://www.who.int/news-room/fact-sheets/detail/dengue-andsevere-dengue. [Last accessed on 2021 May 19].

6. Arsin AA. Epidemiologi Demam Berdarah Dengue (DBD) di Indonesia. $1^{\text {st }}$ ed. Makassar: Masagena Press; 2013.

7. Bachtiar SP, Arusnan AA, Arsyad DS. Factors toward dengue haemorrhagic fever occurrence in Patte'ne village, North Wara district, Palopo city. Indian J Public Health Res Dev. 2019;10(7):1085-9. https://doi. org/10.5958/0976-5506.2019.01726.1

8. Arsin AA, Istiqamah SN, Elisafitri R, Nurdin MA, Sirajuddin S, Pulubuhu DA, et al. Correlational study of climate factor, mobility and the incidence of dengue hemorrhagic fever in Kendari, Indonesia. Enferm Clín. 2020;30:280-4

9. Zamli Z, Syafar M, Palutturi S, Suriah S, Arsunan AA, Hatta $H$, Amiruddin R. Potential of rainfall, humidity and temperature, against the increasing of larvae in Makassar city, Indonesia. Int J Innov Technol Exp Eng. 2019;9(1):1485-7. https://doi. org/10.35940/ijitee.a4296.119119

10. Arsunan AA, Muis M, Ansar J, Amiruddin R, Dwinata I, Nurdin MA, et al. Positive deviance approach; an efforts to reduce the incidence of dengue hemorrhagic fever (DHF) in pangkep regency. Eur J Mol Clin Med. 2020;7(8):160-7.

11. Madjid A, Muhammad S, Arsunan AA, Maria IL, Abdullah T, RussengR. Effectofknowledgeandattitudefactorsontuberculosis incidents in Mandar ethnic in the district of Majene West Sulawesi. Indian J Public Health Res Dev. 2019;10(8):1935- 9. https://doi.org/10.5958/0976-5506.2019.02135.1

12. Nuddin A, Asiah N, Dangnga MS, Arsunan AA, Yusriani $Y$, Handayani S. Institutional strengthening as an anticipatory measure for dengue virus transmission to reduce the incidence 
of dengue fever. Enferm Clín. 2020;30(2):424-8. https://doi. org/10.1016/j.enfcli.2019.07.129

PMid:32204203

13. Taslim M, Arsunan A, Ishak H, Nasir S, Usman AN. Diversity of dengue virus serotype in endemic region of South Sulawesi Province. J Trop Med. 2018;2018:1-4. https://doi. org/10.1155/2018/9682784

14. Dinkes Kabupaten Maros. Profil Kesehatan Kabupaten Maros. Maros: Dinas Kesehatan Kabupaten Maros; 2017. https://doi. org/10.31850/jdm.v2i1.359

15. Rahayu Y, Budi IS, Yeni Y. Analysis of the participation of Jumantik cadres in efforts to combat dengue hemorrhagic fever (DHF) in the work area of indralaya puskesmas. J IImu Kesehatan Masyarakat (JIKM). 2017;8(3):200-7. https://doi. org/10.26553/jikm.2017.8.3.200-207

16. Supriyana S, Saptiwi B, Rimbyastuti H, Warijan W. Establishment of the One House One Jumantik Program in Order to Control Dengue Fever (DF). Link. 2016;12(2):83-5. https://doi.org/10.31983/link.v12i2.1274

17. Moreira ZD, Setyobudi A, Ndun HJ. The correlation between $3 \mathrm{M}+$ behavior and the incidence of dengue hemorrhagic fever in Kupang city. Lontar J Community Health. 2020;2(1):34-43. https://doi.org/10.35508/ljch.v2i1.2824

18. Marlinae L, Ulfah N, Mahardika SR, Dewi SL, Rahmayani S, Zubaidah T. Study of environmental management on the event of dengue hemorrhagic fever (DHF) in Banjarbaru city, Kalimantan Selatan. Indian J Public Health Res Dev. 2019;10(12):1867-71. https://doi.org/10.37506/v10/i12/2019/ijphrd/192139
19. Zaki R, Roffeei SN, Hii YL, Yahya A, Appannan M, Said MA, et al. Public perception and attitude towards dengue prevention activity and response to dengue early warning in Malaysia. PLoS One. 2019;14(2):e0212497. https://doi.org/10.1371/ journal.pone.0212497

PMid:30818394

20. Utama B, Abdullah AZ, Amqam H, Saleh LM, Elisafitri $R$, Usman $\mathrm{AN}$, et al. The influence of interpersonal communication toward knowledge and attitude prevention of dengue fever (DHF) in the work area of the Meo-Meo public health center in Baubau city. Eur J Mol Clin Med. 2020;7(3):1318-25. https://doi. org/10.37506/ijfmt.v15i1.13529

21. Lee JS, Carabali M, Lim JK, Herrera VM, Park IY, Villar L, et al. Early warning signal for dengue outbreaks and identification of high risk areas for dengue fever in Colombia using climate and non-climate datasets. BMC Infect Dis. 2017;17(1):480. https:// doi.org/10.1186/s12879-017-2577-4

22. Hasanah N. Health Education in Increasing Prevention Behavior of Dengue Hemorrhagic Fever in Families at Gubeng Village, Surabaya, Indonesia. Indian J Public Health Res Dev. 2019;10(11):1977-81. https://doi. org/10.5958/0976-5506.2019.03845.2

23. Baequni, Nasir MN, Adhiyanto C. Attitude and preventive behavior of dengue hemorrhagic fever among elementary school students in Jakarta, Indonesia. Asian J Microbiol Biotechnol Environ Sci. 2019;21(4):1028-32.

24. Rasmanto MF, Sakka A, Ainurafiq A. Prediction model of dengue hemorrhagic fever (DHF) based on climate elements in Kendari city 2000-2015. JIMKESMAS. 2016;1(3):1-14. 